To Maega $\mid$ Jurnal Pengabdian Masyarakat

Agustus 2021, Vol.4, No.2, hal, 196-207

$\operatorname{ISSN}(P): 2622-6332 ; \operatorname{ISSN}(E): 2622-6340$

http://www.ojs.unanda.ac.id/index.php/tomaega

\title{
Pengembangan Usaha Kampus Melalui Inovasi Teknologi Budidaya Ikan Nila Dengan Sistem Modular pada Kolam Terpal Di Kabupaten Pangkajene Kepulauan
}

\author{
Jayadi ${ }^{{ }^{*}}$, Andi Asni ${ }^{1}$, Ilmiah ${ }^{1}$, Ida Rosada ${ }^{2}$ \\ ${ }^{1}$ Fakultas Perikanan dan Ilmu Kelautan, Universitas Muslim Indonesia \\ ${ }^{2}$ Fakultas Pertanian Universitas Muslim Indonesia
}

CorrespondentEmail:jayadi.jayadi@umi.ac.id/jayadifartrial@yahoo.com

Article History:

Received: 28-05-2021; Received in Revised: 25-06-2021; Accepted: 06-07-2021

DOI: http://dx.doi.org/10.35914/tomaega.v4i2.753

\begin{abstract}
Abstrak
Program Pengembangan Usaha Produk Intelektual Kampus (PPUPIK) Berbasis Usaha Akuakultur Terpadu melalui inovasi teknologi budidaya ikan nila dikolam terpal dengan sistem modular di Desa Mandalle Kecamatan Mandalle, Kabupaten Pangkep Sulawesi Selatan. Program ini bertujuan untuk mengembangkan ekonomi kampus, menanamkan budaya wirausaha bagi mahasiswa, percontohan untuk masyarakat dan tempat praktek untuk mahasiswa Kolam terpal pemeliharan pendedaran (1 kolam) dan pembesaran (2 kolam) dengan diameter $3 \mathrm{~m}$ dan tinggi 1,2 $\mathrm{m}$. Benih ikan yang digunakan adalah nila Gesit (Oreochromis niloticus) yang mono sex jantan, berukuran $1,5 \mathrm{~cm}$. Selama pendederan dilakukan penyiponan setiap hari dan diberi probiotik $50 \mathrm{ml} / \mathrm{minggu}$. Ukuran benih untuk pembesaran yaitu $5-7 \mathrm{~cm}$ sebanyak 1500 ekor setiap kolam. Media pemeliharaan dikolam pembesaran dengan menumbuhkan bioflok dan makanan alami sebelum benih ditebar. Pergantian air dilakukan setiap minggu. Pakan buatan yang digunakan berkadar protein $35 \%$, frekwensi pemberian pakan 3 kali sehari, dan dosis pemberian pakan 3-5\% dari berat tubuh. Kelangsungan hidup ikan untuk pendederan yaitu $87 \%$. Total produksi ikan konsumsi satu siklus pembesaran $1.053 \mathrm{~kg}$. Keuntungan produk ikan nila $R p$. 15.125.000. RC ratio menunjukkan $1,35>1$ berarti layak dilaksanakan dengan payback periode sebesar 0,32 tahun.
\end{abstract}

Kata kunci : ikan nila, modular, probiotik, B/C ratio, akuakultur

\begin{abstract}
Campus Intellectual Product Business Development Program (PPUPIK) based on Integrated Aquaculture Business through innovative tilapia cultivation technology in ponds with a modular system, located in Mandalle Village, Mandalle District, Pangkep Regency, South Sulawesi. The program aims to develop the campus economy, instill an entrepreneurial culture for students, a model for the community and a place of practice for students. Maintenance in ponds for nurseries (1 pond) and growing (2 ponds) were 3 $m$ in diameter and $1.2 \mathrm{~m}$ high. The fish seed species used were Oreochromis niloticus which was mono-sex male, $1.5 \mathrm{~cm}$ in size. During the nursery, water suction were carried out every day and given probiotics $50 \mathrm{ml} /$ week. The size of the seeds for enlargement is $5-7 \mathrm{~cm}$ as many as 1500 individuals per ponds. Water is in the growing pond was growth of biofloc and natural food. Water changes were carried out every week. Tilapia survival for nursery was $87 \%$. The total production of consumption fish was $1,053 \mathrm{~kg}$.
\end{abstract}


Artificial feed was used with a protein content of 35\%, feeding frequency were 3 times a day and dose were 3-5\% of body weight. The profit of consumption fish products was Rp. 15,125,000. $R C$ ratio shows $1.35>1$ means it is feasible to be implemented with a payback period of 0.32 years.

Keywords: tilapia, modular, probiotic, B / C ratio, aquaculture

\section{Pendahuluan}

Dalam rangka mempercepat proses pengembangan wirausaha baru bersifat mandiri dalam memanfaatkan pengetahuan dan teknologi dan riset dari kampus untuk mendukung pengembangan kemandirian ekonomi kampus, maka dikembangkan Budidaya ikan nila (Oreochromis niloticus). Ikan nila merupakan komoditas unggulan air tawar dan memiliki keunggulan kompartif karena rasa dagingnya yang khas dan gurih dengan kandungan omega dan gizi yang cukup tinggi, pertumbuhan yang cepat, memiliki batasan toleransi yang cukup tinggi terhadap berbagai kondisi lingkungan perairan, mudah berkembangbiak, pemakan segala bahan makanan, memiliki daya adaptif yang luas, dan toleransinya yang tinggi terhadap berbagai kondisi salinitas (Robisalmi dkk, 2020).

Untuk mendukung permintaan ikan nila terus mengalami peningkatan setiap tahunnya. Saat ini ikan nila juga disebut sebagai aquatic chicken bahkan saat ini telah dikenal sebagai aquatic turkey karena banyak digemari masyarakat (Perschbacher, 2014) dan termasuk salah satu komoditas unggulan memiliki daya saing yang tinggi di pasar ekspor dan mampu berperan sebagai penopang ketahanan pangan dengan target produksi tahun 2021 sebesar 1.719 .000 ton (Keputusan Dirjen Perikanan Budidaya No. 272/KEP-DJPB/2020 tanggal 30 Juli 2020). Oleh karena itu, pengembangan budidaya ikan nila memiliki prospek usaha yang cukup menjanjikan dalam mendukung ketahanan pangan nasional maupun ketahanan ekonomi serta peningkatan kesejahteraan masyarakat (Marie dkk, 2018). Sebagai tindak lanjut untuk mendukung hal tersebut, maka kegiatan budidaya ikan nila sudah dikembangkan baik di air tawar, payau maupun laut dengan teknik budidaya monokultur, polikultur, tradiosional, semi intensif, intesif, dan modular pada kolam tanah, kolam tembok, kolam terpal dan keramba jaring apung dengan implementasi Cara Budidaya Ikan yang Baik (CBIB). Produksi ikan Nila pada tahun 2018 sudah mencapai 1.169.144,54 ton (Kementerian Kelautan dan Perikanan, 2019).

Salah satu kegiatan untuk menopang pengembangan produksi ikan nila, maka Fakultas Perikanan dan Ilmu Kelauatan, Universitas Muslim Indonesia membuat sentra percontohan inovasi teknologi budidaya ikan nila dikolam terpal dengan sistem modular melalui Program Pengembangan Usaha Produk Intelektual Kampus (PPUPIK) di Kabupaten Pangkajene Kepulauan (Pangkep) berbasis usaha akuakultur terpadu. Kegiatan ini merupakan salah satu program Direktorat Riset dan Pengabdian Masyarakat, Deputi Bidang Penguatan Riset danPengembangan, Kementerian Riset dan Teknologi / Badan Riset dan Inovasi 
Nasional, tahun anggaran 2019-2021. Manfaat yang diharapkan dari program ini dapat menjadi dempolt percontohan sebagai pusat pelatihan dan penyuluhan budidaya ikan nila serta menjadi tempat praktek kerja lapang untuk menujang Program Merdeka Belajar Kampus Merdeka (PMBKM) bagi mahasiswa

\section{Metode}

Lokasi budidaya ikan nila di kolam terpal bundar dengan sistem modular di Desa Mandalle Kecamatan Mandalle, Kabupaten Pangkep Sulawesi Selatan pada bulan September 2020 sampai Februari 2021. Inovasi teknologi yang dilakukan dengan menerapkan sistem budidaya modular yaitu sistem pemeliharaan berpindah dari satu tempat pemeliharaan ke tempat pemeliharaan lainnya (kolam terpal). Kegiatan dimulai dari pemeliharan benih di kolam terpal selama 1 bulan (pendederan benih). Selanjutnya, ikan dipindahkan ke kolam terpal lainnya untuk pembesaran sampai ukuran konsumsi selama 4 bulan

Benih ikan yang ditebar adalah nila gesit (Oreochromis niloticus) mono sex jantan dari kelompok pembudidaya ikan air tawar Kora-Kora Putelapa, Desa Buakkang, Kabupaten Gowa sebanyak 5.000 ekor. Ukuran benih 1,5 cm dengan bobot tubuh 0,2 g. Wadah pemeliharaan pendederan digunakan kolam terpal diameter $3 \mathrm{~m}$ dan tinggi 1,2 $\mathrm{m}$ (Gambar 1). Kolam terpal diisi air setinggi $1 \mathrm{~m}$ dan diatur peletakan aerasinya. Selama pemeliharan kolam ditutup dengan waring.
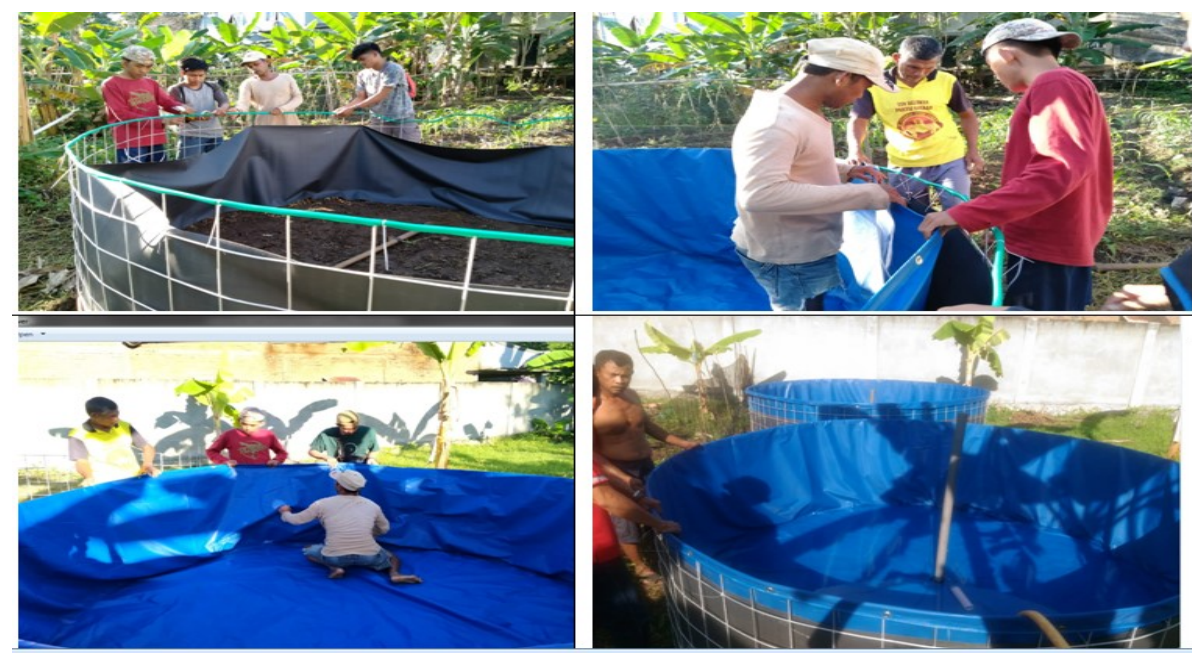

Gambar 1. Pemasangan kolam terpal

Benih yang akan ditebar dilakukan aklimatisasi suhu selama 10-15 menit dan selanjutnya kantong plastic dibuka dan benih dibiarkan keluar sendiri ke kolam pendederan. Pemberian pakan buatan dilakukan 6 jam setelah benih ditebar. Pakan buatan yang digunakan berkadar protein $35 \%$ dan dicampur probiotik. Frekwensi pemberian pakan 3 kali sehari dengan dosis 3-5\% dari berat total benih. Selama pemeliharaan penyiponan sisa pakan dan feces ikan dilakukan setiap hari dan ditambah air sesuia air yang terbuang. Pengukuran kualitas air 
dilakukan mengukur suhu, $\mathrm{pH}$, dan oksigen (DO). Setiap minggu diberi probiotik sebanyak $50 \mathrm{ml}$. Pemeliharan benih dikolam pendederan selama 30 hari.

Kolam terpal untuk pembesaran disiapkan sebanyak 2 unit. Kedua kolam tersebut masing-masing ditebar ikan nila sebanyak 15000 ekor. Wadah pemeliharaan pembesaran digunakan kolam terpal diameter $3 \mathrm{~m}$ dan tinggi 1,2 $\mathrm{m}$. Kolam terpal diisi air setinggi $1 \mathrm{~m}$ atau volume air $7 \mathrm{~m}^{2}$ dan diatur peletakan aerasinya. Sebelum ikan ditebar dikolam pembesaran, terlebih dahulu dilakukan persiapan media pemeliharan dengan menumbuhkan bioflok dan makanan alami. Pemberian probiotik selama persiapan air sebanyak 2 liter. Persiapan media tersebutr dilakukan selama 10 hari sebelum ikan ditebar.

Setelah tumbuh makanan alami dan bioflok dilakukan penebaran benih ukuran $5-7 \mathrm{~cm}$ dari hasil pendederan. Pakan buatan yang digunakan selama pembesaran berkadar protein $35 \%$ dan sudah diberi probiotik. Frekwensi pemberian pakan dilakukan 3 kali sehari dengan dosis 3-5\% dari berat tubuhnya. Pergantian air dilakukan setiap minggu dengan memperhatikan kedaan makanan alami dan pertubuhan bioflok. Pematauan pertumbuhan dilakukan setiap 7 hari dengan mengukur pertubuhan berat dan panjang total.

Penerimaan, pendapatan dan efisiensi produksi kegiatan budidaya ikan nila di kolam terpal bundar dengan sistem modular dapat diestimasi menurut Rajab (2016) sebagai berikut :

a. Formulasi matematika penerimaan

$\mathrm{TR}=\mathrm{Q} \times \mathrm{P}$, dimana $\mathrm{TR}$ adalah penerimaan $(\mathrm{Rp}), \mathrm{Q}$ adalah jumlah produksi yang dihasilkan $(\mathrm{kg})$ dan $\mathrm{P}$ adalah harga produk ( $\mathrm{Rp})$.

b. Formulasi matematikan pendapatan

$\mathrm{II}=\mathrm{TR}-\mathrm{TC}$, dimana II adalah pendapatan, TR adalah total penerimaan dan TC adalah total biaya yang digunakan.

c. Formulasi matematikan $\mathrm{R} / \mathrm{C}$ ratio, sebagai berikut;

$\mathrm{R} / \mathrm{C}$ ratio $=($ Total TC Revenue $) /($ Total Cost $)$

Untuk mengetahui besarnya keuntungan yang diperoleh selama kegiatan ini dengan kriteria : jika $\mathrm{R} / \mathrm{C}>1=$ menguntungkan jika $\mathrm{R} / \mathrm{C}<=$ tidak menguntungkan dan $\mathrm{R} / \mathrm{C}=1$ yaitu impas. Analisis finasial bertujuan untuk mengetahui perkiraan dalamhal pendanaan dan aliran kas, sehingga dapat diketahui layak atau tidaknya bisnis yang dijalankan.

\section{Hasil dan Pembahasan}

\section{Aspek teknik peksanaan budidaya}

a. Pendederan benih ikan nila

Media pemeliharan ikan di kolam pendederan dipersiapkan 10 hari sebelum benih ditebar. Langkah awal yang dilakukan membersihkan kolam terpal dengan mencunci dan menjemur. selama satu hari. Selanjutnya kolam pendederan di isi air setinggi $1 \mathrm{~m}$ dan diberi probiotik $50 \mathrm{ml}$. Kondisi suhu air pada waktu 
penebaran/aklimatisasi benih ikan nila yaitu $28.9^{\circ} \mathrm{C}$. Salah satu kegiatan yang dilakukan pada saat penebaran benih kedalam kolam pemdederan adalah akimatisasi benih. Proses aklimatisasi ikan terhadap media pemeliharaan di kolam pendederan (Gambar 2) yaitu mengapungkan kantong plastik yang berisi benih ikan nila selama 5-10 menit. Suhu media pemeliharaan di kolam pendederan sewaktu aklimatisasi $28^{\circ} \mathrm{C}$.

Aklimatisasi merupakan proses penyesuaian dua kondisi lingkungan yang berbeda sehingga kondisi tersebut tidak menimbulkan stress bagi ikan Aklimatisasi merupakan suatu upaya mengatur morfologi tubuh dan penyesuaian fisiologis suatu organisme terhadap suatu lingkungan baru yang akan dimasukinya (Arianto dkk, 2018). Hal ini didasarkan pada kemampuan organisme untuk dapat mengatur morfologi, perilaku dan jalur metabolisme biokimia di dalam tubuhnya untuk menyesuaikannya dengan lingkungan yang dimasuki.
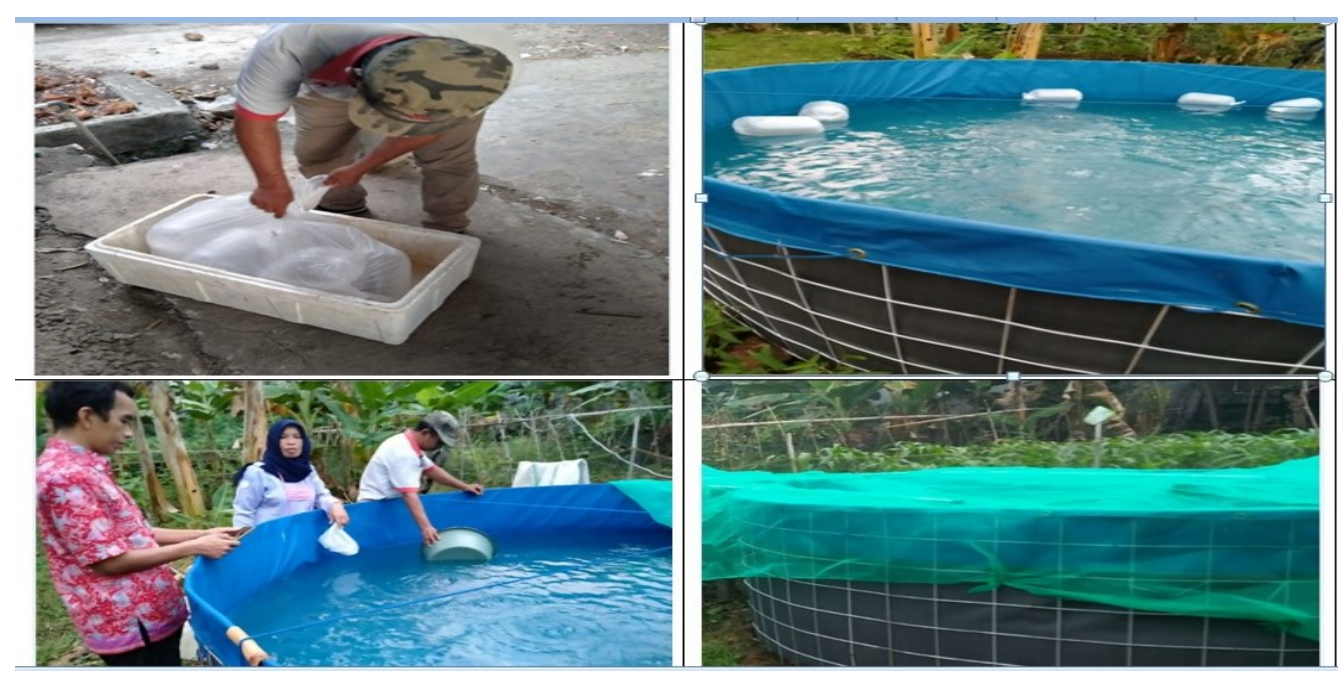

Gambar 2. Penebaran benih, proses aklimatisasi benih dan penutupan kolam terpal

Pengelolaan media pemeliharan ikan selama pendederan dilakukan dengan menyipong sisa pakan dan feses ikan setiap hari. Pakan buatan yang diberikan disesuaiakan dengan bukaan mulut benih dengan kadar protein $35 \%$. Frekwensi pemberian pakan dilakukan 3 kali sehari yaitu jam 7.00-7.30; jam 12.00- 13.00 dan jam 5.30-6.00. Dosis pakan yang diberikan 3-5 \% dari berat total. Pakan yang diberikan terlebih dahulu direndam di dalam probiotik selama 5-10 menit sebelum diberikan. Ukuran benih yang dihasilkan setelah didederkan selama 30 hari yaitu panjang total 5 - $7 \mathrm{~cm}$ dengan berat 4 - 6 g. Kelangsungan hidup ikan nila selama pendederan adalah $87 \%$.

b. Pembesaran ikan nila

Persiapan dua kolam pembesaran dilakukan dengan menyiapkan media pemeliharan dengan mengisi air tawar setinggi 1 meter pada kolam terpal ukuran diameter $3 \mathrm{~m}$. Persiapan ini dilakukan 10 hari sebelum ikan ditebar dengan menumbuhkan bioflok dan makanan alami. Setiap kolam pembesaran ditebar 
15000 ekor benih ukuran 5-7 cm. Pakan buatan yang diberikan berkadar protein $35 \%$. Frekwesi pemberian pakan 3 kali sehari yaitu jam 7.00-7.30; jam 12.0013.00 dan jam 5.30-6.00. Dosis pakan yang diberikan 3-5\% dari berat total.. Pergantian air dilakukan setiap minggu sebanyak $50 \%$. Setiap bulan dilakukan sampling pertubuhan (Gambar3). Produksi ikan konsumsi selama pemeliharaan 4 bulan sebanyak $521 \mathrm{~kg}$ pada kolam A dan $532 \mathrm{~kg}$ pada kolam B. Total produksi untuk satu siklus pemeliharaan $1.053 \mathrm{~kg}$.

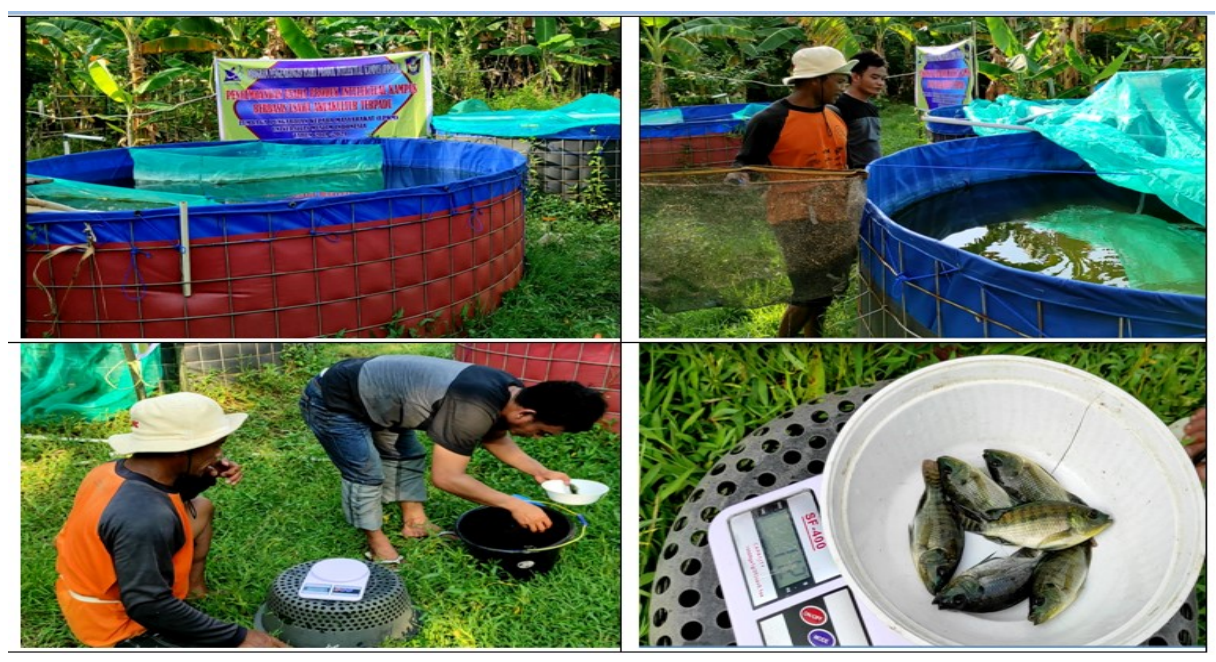

Gambar 3. Sampling ikan dan penimbangan berat

\section{Aspek manajemen pemberian pakan}

Manajemen pemberian pakan merupakan salah satu kegiatan untuk memaksimalkan pertumbuhan dan kelangsungan hidup ikan yang dibudidayakan. Pakan merupakan sumber materi dan energi untuk menopang kelangsungan hidup dan pertumbuhan ikan (Hanef dkk, 2014). Kecepatan pertumbuhan ikan sangat dipengaruhi oleh jenis dan kualitas pakan yang diberikan serta kondisi lingkungan hidupnya (Amri dan Khairuman, 2013 ). Pakan yang baik adalah pakan yang sesuai dengan kebutuhan fisiologi dan spesies ikan yang dibudidayakan. Disamping mampu untuk memenuhi kebutuhan nutrisi ikan tersebut, pemberian pakan dengan kualitas dan kuantitas yang baik dapat mengoptimalkan usaha budidaya ikan (Niode dkk, 2017).

Protein berperan sebagai sumber berbagai zat yang menentukan pertumbuhan ikan. Kebutuhan protein untuk pertumbuhan ikan berbeda menurut jenis dan ukurannya (Fernandes dkk, 2016). Protein termasuk komponen organik utama yang bahannya dari jaringan tubuh hewan, $65-75 \%$ protein yang berperan sebagai sumber energi dan sebagai zat pembangun dan pengatur untuk pertumbuhan (Yanti dkk, 2013). Benih nila berumur \pm 2 bulan membutuhkan pakan buatan (granular) berkadar protein 25-50\% (Kordi, 2013). Selama pemeliharaan ikan mulai dari pendederan sampai pembesaran digunakan pakan buatan berkadar protein $35 \%$ 
Frekuensi pemberian pakan ikan dengan jumlah pakan yang tepat akan memaksimalkan pemanfaatan pakan oleh ikan sehingga diharapkan pertumbuhan ikan akan maksimal, efisiensi biaya produksi dan mengurangi pencemaran lingkungan (Hanef dkk, 2014). Ikan hanya mengkonsumsi pakan ketika lambung mendekati waktu kosong atau ketika ikan benar-benar lapar sehingga nafsu makan pada ikan akan meningkat (Tahapari dan Suhenda, 2009). Oleh karena itu Jumlah pakan yang diberikan harus sesuai dengan kapasitas lambung dan kecepatan pengosongan lambung atau waktu ikan membutuhkan pakan perlu diperhatikan. Frekwesi pemberian pakan dilakukan selama pendederan dan pembesaran ikan nila di kolam terpal yaitu jam 7.00-7.30; jam 12.00- 13.00 dan jam 5.30-6.00.

Pemberian pakan dengan dosis yang optimum akan diperoleh efisiensi pakan yang optimal dan menekan penurunan kualitas lingkungan budidaya. Dosis pakan yang diberikan 3-5 \% dari berat total dalam pemeliharan ikan nila menunjukan peningkatan pertumbuhan dan menekan kematian benih. Dosis Pakan yang tidak sesuai kebutuhan ikan (terlalu banyak) akan merusak kualitas air yang diakibatkan oleh endapan sisa pakan yang tidak dimanfaatkan menjadi amoniak dan bakteri merugikan akan berkembang dan akhirnya berpengaruh pada pertumbuhan ikan Nila (Zulkhasyni dkk, 2017)

\section{Aspek manajemen teknologi bioflok}

Teknologi bioflok menjadi salah satu alternatif pemecah masalah limbah budidaya, karena dapat menurunkan limbah nitrogen anorganik dari sisa pakan dan kotoran (Sukardi dkk, 2018) . Teknologi bioflok dapat memperbaiki kualitas air dan meningkatkan efisiensi pemanfaatan nutrient (Ombong dan. Salindeho, 2016). Teknologi bioflok dilakukan dengan menambahkan karbohidrat organik kedalam media pemeliharaan untuk meningkatkan rasio $\mathrm{C} / \mathrm{N}$ dan merangsang pertumbuhan bakteri heterotrof yang dapat mengasimilasi nitrogen anorganik menjadi biomasa bakteri (Suryaningrum,2014).

Teknologi bioflok menjadi penyedia pakan tambahan berprotein untuk ikan budidaya sehingga dapat menaikkan pertumbuhan dan efisiensi pakan (Sukardi dkk, 2018). Teknologi bioflok dapat memproduksi bakteri heterotrof menjadi biomassa mikroba yang dapat dikonsumsi oleh ikan budidaya untuk membantu kecernaan pakan (Nadya dkk, 2016) Bahan yang digunakan untuk produksi flok dalam pemeliharan ikan nila yaitu dedak, garam, molase, daun pepaya, kunyit dan bakteri probiotik (EM4). Proses pembentukan flok awal membutuhkan waktu selama 7-10 hari. Probiotik dengan kandungan mikroba terutama bakteri asam laktat dan ragi berfungsi meningkatkan daya cerna penyerapan nutrisi dan efisiensi penggunaan ransum pakan (Suminto dan Chilmawati, 2015).

Probiotik merupakan salah jenis bakteri fotosintetik yang mampu meningkatkan efisiensi pemanfaatan pakan dan pertumbuhan ikan (Noviana dkk, 2014). Probiotik merupakan bakteri fotosintetik, seperti Lactobacillus sp, 
Actinomycetes sp, Streptomycetes sp, dan ragi (Putri dkk, (2012). Bakteri tersebut akan mensekresikan enzim-enzim pencernaan seperti protease dan amilase didalam saluran pencernaan (Setiawati dkk,. 2013). Penggunaan probiotik dalam pakan ikan mampu meningkatkan kecernaan dan pertumbuhan ikan nila (Lasena $\mathrm{dkk}$, 2017). Pertumbuhan terjadi apabila nutrisi pakan yang dicerna dan diserap oleh tubuh ikan lebih besar dari jumlah yang diperlukan untuk memelihara tubuhnya (Yanti dkk, 2013). Pengunaan probiotik pada pemeliharaan ikan dapat menghambat bakteri patogen dalam saluran pencernaan (Latifa dkk, 2016), meningkatkan sistim imun ikan (Umasugi dkk, 2018). Jenis mikroorganisme yang terdapat dalam probiotik .EM4 (Effective Microorganisme 4) yang diberikan pada kegiatan pemeliharan ikan nila adalah: Lactobacillus acidophilus, Saccharomyces cerevisiae,Aspergillus oryzae, Rhodopseudomonas, Bacillus subtilis, nitrobacter dan Actinomycetes (Anis dan Hariani, 2019).

\section{Aspek manajemen pengelolaan media pemeliharaan}

Pengelolaan media pemeliharan ikan selama pendederan dilakukan dengan menyipong sisa pakan dan feses ikan setiap hari. Pengelolaan air di kolam pembesaran ikan dengan melakukan pergantian air setiap minggu sebanyak $50 \%$. Pengelolaan kualitas air untuk keperluan budidaya sangat penting, karena air mempengaruhi aktivitas metabolism organisme (Panggabean dkk, 2016). Kualitas air selama pendederan benih ikan nila selama 30 hari yaitu suhu sekitar 28,7 $30,5^{\circ} \mathrm{C}$, pH 7,2 -8,1 dan DO 5,6 - 6,0 mg/l, sedangkan kondisi media kolam pembesaran ikan nila yaitu suhu $27,9-31,5^{\circ} \mathrm{C}$, pH 7,7 -8,7 dan DO 5,9-6,9 $\mathrm{mg} / \mathrm{l}$. Kisaran suhu selama pemeliharan ikan nila sudah sesuai dengan BNSI (2009) adalah $25-32{ }^{\circ} \mathrm{C}$. Amri dan Khairuman (2013) menyatakan bahwa ikan nila dapat tumbuh secara normal pada kisaran suhu $14-38^{\circ} \mathrm{C}$. Kisaran $\mathrm{pH}$ juga sudah sesuai hasil pemeliharaan yaitu kisaran $\mathrm{pH} 8,0-8,6$ (Nugroho dkk, 2013) dan $\mathrm{pH}$ yang optimal untuk kegiatan pembesaran ikan nila adalah 6,5-8,5 (BSN 7550: 2009). Kandungan oksigen selama pemeliharan ikan di kolam terpal berkisar 5,6 $6,9 \mathrm{mg} / \mathrm{l}$. Hal tersebut sudah sesuai kandungan oksigen adalah berkisar 3,2-3,8 $\mathrm{mg} / \mathrm{L}$ (Wijayanti dkk, 2019), maka dapat dikatakan bahwa nilai kandungan oksigen terlarut selama pemeliharaan benih ikan sudah layak. Menurut (BSN 7550: 2009), bahwa kandungan oksigen terlarut dalam media budidaya ikan nila harus lebih tinggi dari 3,0 $\mathrm{mg} / \mathrm{L}$.

\section{Aspek analisis finansial}

Analisis ekonomi atau finasial sebagai metode penilaian program Usaha Produk Intelektual Kampus (PPUPIK) Berbasis Usaha Akuakultur Terpadu di Kabupaten Pangkep tentang pengembangan teknologi budidaya ikan nila dengan sistem modular di kolam terpal dapat dikatakan layak atau tidak untuk dilanjutkan/diteruskan. Karena dalam analisis finansial program ini akan diketahui keadaan yang mencerminkan perkembangan usaha, terutama untuk masa jangka 
panjang, terlihat adanya perkembangan finansialnya (Jayadi dkk, 2020). RC-ratio merupakan nilai yang digunakan untuk menentukan tingkat kelayakan suatu usaha merupakan nisbah total revenue dengan total biaya $R C$ ratio $=$ yang diperoleh dari kegiatan ini yaitu 1,35>1 (Tabel 1 dan Tabel 2) berarti inovasi teknologi budidaya ikan nila dengan sistem modular di kolam terpal di Kabupaten Pangkep layak untuk dilaksanakan. Penggunaan bioflok dalam kegiatan ini dapat menumbuhkan bioflok dan makanan alami sehingga biaya pakan dapat ditekan, namun untuk pengembangan kedepannya perlu membuat pakan mandiri.

Tabel 1. Komponen biaya tetap (biaya investasi) program pengembangan teknologi budidaya ikan nila sistem modular di kolam terpal

\begin{tabular}{clcrrr}
\hline No & Komponen & Jumlah & Umur ekonomis/thn & Satuan Harga (Rp) & \multicolumn{1}{c}{ Jumlah Harga (Rp) } \\
\hline 1 & Sewa lahan & 1 & & 2.000 .000 & 1.000 .000 \\
\hline 2 & Kolam terpal & 3 & 8 & 1.250 .000 & 3.750 .000 \\
\hline 4 & Timbangan & 1 & 5 & 350.000 & 350.000 \\
\hline 5 & $\begin{array}{l}\text { Peralatan suplai } \\
\text { oksigen }\end{array}$ & 1 & 5 & 750.000 & 750.000 \\
\hline 6 & Pompa air & 1 & 5 & 500.000 & 500.000 \\
\hline 7 & Sodo & 1 & 2 & 75.000 & 75.000 \\
\hline 8 & Selang & 1 & 3 & & 300.000 \\
\hline & \multicolumn{2}{r}{ Total Biaya Tetap } & & 6.725 .000 \\
\hline
\end{tabular}

Tabel 2. Komponen biaya variable program pengembangan teknologi budidaya ikan nila sistem modular di kolam terpal

\begin{tabular}{llcrr}
\hline No & Komponen & Jumlah & $\begin{array}{c}\text { Satun Harga } \\
(\mathrm{Rp})\end{array}$ & \multicolumn{2}{c}{$\begin{array}{c}\text { JumlahHarga } \\
(\mathrm{Rp})\end{array}$} \\
\hline 1 & Bibit ikan nila & 5.000 & 100 & 500.000 \\
\hline 2 & Pakan buatan untuk pendederan & 2 & 350.000 & 700.000 \\
\hline & Pakan buatan untuk pembesaran & 8 & 250.000 & 2.000 .000 \\
\hline 3 & Probiotik & 20 & 25.000 & 500.000 \\
\hline 4 & Tenaga kerja & 1 & 750.000 & 750.000 \\
\hline 5 & Kapur & 1 & 25.000 & 25.000 \\
\hline 6 & Pembuatan bioflok & 5 & 100.000 & 500.000 \\
\hline 7 & Listrik & 5 & 100.000 & 500.000 \\
\hline & & & & 5.475 .000 \\
\hline
\end{tabular}

Penerimaan Kolam I: 532 kg/ Rp. $25.000=$ Rp. 13.300 .000

Penerimaan Kolam II: 521 kg/ Rp. $25.000=$ Rp. 13.025.000

Pendapatan (penerimaan) 2 kolam:Rp. 13.300.000+ Rp. 13.025.000=Rp. 26.320 .000

Total Biaya : $6.725 .000+5.475 .000=\mathrm{Rp} .11 .195 .000$

Laba:Rp. 26.320.000- Rp. $11.195 .000=$ Rp. 15.125 .000

$R / C$ ratio $=($ Total TC Revenue $) /($ Total Cost $):$ Rp. $15.125 .000 /$ Rp. $11.195 .000=1,35>1($ menguntungkan)

Penyusutan pertahun $=$ Rp. $2,520.000$

Cash flow : laba + penyusutan $=15.125 .000+2.520 .000=17.645 .000$

Pay back periode $=: 6.725 .000 / 17.645 .000=0,38$ tahun $(4,57$ bulan $)$ 
Inovasi tenologi yang diterapkan pada usaha kampus Universitas muslim Indonesia pada Program Produk Intelektual Kampus (PPUPIK) Berbasis Usaha Akuakultur Terpadu di Kabupaten Pangkep dengan pengembangan usaha budidaya ikan nila secara sistem modular di kolam terpal dengan nilai kelayakan $\mathrm{R} / \mathrm{C}$ yaitu 1,35 berarti inovasi tersebut layak dilakukan dan pay back periode sebesar 0,32 tahun menunjukkan bahwa periode pemeliharaan 4 bulan investasi yang ditanamkan sudah kembali. Kegiatan ini dapat meningkatkan pengetahuan dan keterampilan mahasiswa sehingga merangsang mahasiswa menjadi wirausaha baru dan dapat menjadi sumber ekonomi baru untuk kampus.

\section{Kesimpulan}

Penerapan teknologi budidaya ikan nila di kolam terpal dengan sistem modular layak menjadi salah satu pilihan pengembangan budidaya ikan nila dengan nilai $\mathrm{R} / \mathrm{C}$ adalah 1,35 dengan pay back periode sebesar 0,32 tahun. Aspek manajemen pengelolaan media pemeliharaan, pengelolaan pakan dan pengelolaan penggunaan probiotik perlu diperhatikan dalam usaha budidaya ikan nila.

\section{Ucapan Terimakasih}

Tim pengabdian mengucapkan terima kasih kepada Direktorat Riset dan Pengabdian Masyarakat (Ristekdikti) yang telah mendanai kegiatan Program Pengembangan Usaha Produk Intelektual Kampus (PPUPIK) di Universitas Muslim Indonesia. Tim pengabdian juga mengucapkan terima kasih kepada Ketua Lembaga Pengabdian kepada Masyarakat (LPkM) Universitas Muslim Indonesia yang telah memberikan dukungan mengikuti kegiatan hibah tersebut.

\section{Daftar Pustaka}

Amri, K. dan Khairuman. (2013). Budidaya Ikan Nila. Jakarta: Agro Media Pustaka.

Anis, M.H dan Hariani, D. (2019). Pemberian Pakan Komersial dengan Penambahan EM4 (Effective Microorganisme 4) untuk Meningkatkan Laju Pertumbuhan Lele (Clarias sp.). Jurnal Riset Biologi dan Aplikasinya, 1 (1) $1-8$.

Arianto, R.M., Fitri, A.D.P. Dan Jayanto,B.B. (2018). Pengaruh Aklimatisasi Kadar Garam Terhadap Nilai Kematian dan Respon Pergerakan Ikan Wader (Rasbora argyrotaenia) untuk Umpan Hidup Ikan Cakalang Journal of Fisheries Resources Utilization Management and Technology,7 (2) 43-51. http://www.ejournal-s1.undip.ac.id/ index. php/jfrumt

BSNI. 2009. SNI No.7550:2009 Produksi Ikan Nila (Oreochromis niloticus Bleeker) Kelas Pembesaran di Kolam Air Tenang. Badan Standardisasi Nasional, Jakarta.

Fernandes, H. Peres H and Carvalho, A.P. (2016). Dietary protein requirement during juvenile growth of Zebrafish (Danio rerie).Zebrafish, 13 548-555.

Kordi, A.G (2013).Budidaya Ikan Konsumsi di Air tawar.Lily Publisher, Yokyakarta. 732 hal. 
Hanief, M.A.R. Subandiyono, dan Pinandoyo. (2014). Pengaruh Frekuensi Pemberian Pakan Terhadap Pertumbuhan Dan Kelulushidupan Benih Tawes (Puntius javanicus). Journal of Aquaculture Management and Technology, 3(4) 67- 74.

Jayadi, Asni, A. Ilmiah dan Rosada, I (2020). Pengembangan Sentra Usaha Budidaya Ikan Nila Secara Intensif dengan Sistem Modular di Tambak Universitas Muslim Indonesia, Kalibone Kabupaten Pangkep. Jurmal Pengamas, 3 (1) :74-83.

Kementerian Kelautan dan Perikanan (2019). Peluang Usaha dan Investasi Nila. Direktorat Jenderal Penguatan Daya Saing Produk Kelautan dan Perikanan. 91 hal.

Keputusan Dirjen Perikanan Budidaya No. 272/KEP-DJPB/2020 tanggal 30 Juli 2020. Rencana Strategis 2020-2024 Direktorat Jenderal Perikanan Budidaya, Kementerian Kelautan dan Perikanan. 93 hal.

Marie, R. Syukron, M.A. dan Rahardjo,S.S.P. (2018). Teknik Pembesaran Ikan Nila (Oreochromis niloticus) dengan Pemberian Pakan Limbah Roti. Jurnal Sumberdaya Alam dan Lingkungan.5 (21) 1-6.

Nadya, A. Soewardi,K. Syakti,A.D. dan Hariyadi, S. (2016).Water Quality Management Using Bioflocs Technology: Catfish Aquaculture (Clarias sp.). Jurnal Ilmu Pertanian Indonesia (JIPI), April 2016.

Niode, A.R. Nasriani, dan Irdja. Ad.M. (2017). Pertumbuhan dan Kelangsungan Hidup Benih Ikan Nila (Oreochromis niloticus) pada Pakan Buatan yang Berbeda. Akademika, 6 (2) : 99-112

Noviana,P. Subandiyono.dan Pinandoyo. (2014). Pengaruh Pemberian Probiotik dalam Pakan Buatan terhadap Tingkat Konsumsi Pakan dan Pertumbuhan Benih Ikan Nila (Oreochromis niloticus). Journal of Aquaculture Management and Technology, 3 (4) 183-190.

Nugroho, A.,Arini, E., Elfitasari, T. 2013. Pengaruh Kepadatan yang Berbeda terhadap Kelulushidupan dan Pertumbuhan Ikan Nila (Oreochromis Niloticus) pada Sistem Resirkulasi dengan Filter Arang. Journal of Aquaculture Management and Technology, 2(3) 94-100.

Lasena, A. Nasriani, dan Irdja, Ad,M. (2017). Pengaruh Dosis Pakan yang Dicampur Probiotik Terhadap Pertumbuhan dan Kelangsungan Hidup Benih Ikan Nila (Oreochromis niloticus). Akademika, 6 (2) 65-76

Latifa A. Supriyanto A. dan Rosmanida. (2016). Pengaruh Pemberian Probiotik Dengan Berbagai Dosis Berbeda Untuk Meningkatkan Pertumbuhan Lele Dumbo (Clarias gariepinus). Jurnal Universitas Airlangga. 7 hal.

Ombong, F. dan Salindeho,I.R.N. (2016). Aplikasi Teknologi Bioflok (BFT) pada Kultur Ikan Nila(Orechromis niloticus). Budidaya Perairan, 4 (2) $16-25$.

Panggabean,TK. Sasanti,A.D. dan Yulisman. (2016). Kualitas Air, Kelangsungan Hidup, Pertumbuhan, dan Efisiensi Pakan Ikan Nila yang Diberi Pupuk Hayati Cair pada Air Media Pemeliharaan. Jurnal Akuakultur Rawa Indonesia, 4(1) 67-79.

Perius Y. (2011). Nutrisi Ikan. http://yulfiperius.files.wordpress.com/2011/07/1 pendahuluan.pdf. [Diakses 28 April 2011].

Perschbacher, P.W. (2014). Tilapia: The "Aquatic Chicken"-At Last Journal of Fisheries \& Journal of Fisheries \& Livestock Production, 2(2) 1-2. 
Putri,F.S. Hasan, Z dan Haetami,K. (2012). Pengaruh Pemberian Bakteri Probiotik pada Pelet yang Mengandung Kaliandra(Calliandra calothyrsus) terhadap Pertumbuhan Benih Ikan Nila (Oreochromis niloticus). Jurnal Perikanan dan Kelautan, 3(4) 283-291.

Rajab, N.A (2016). Pengaruh Implementasi Program Pengembangan Usaha Mina Pendesaan Pengelolaan dan Pemasaran Hasil Perikanan Terhadap Peningkatan Pendapatan Kelompok Penglahan dan Pemasar di Kabupaten Gowa. Tesis. Program Pasca Sarjana, Universitas Muslim Indonesia, Makassar 78 hal.

Robisalmi, A. Gunadi ,B. dan Setyawan, P. (2020). Evaluasi Performa Pertumbuhan dan Heterosis Persilangan antara Ikan Nila Nirwana (Oreochromis niloticus) Betina dengan Ikan Nila Biru (Oreochomis aureus) Jantan F2 pada Kondidi Tambak Hipersaliniatas. Berita Biologi, Jurnal Ilmu Ilmu Hayati. DOI: beritabiologi.v19i1.3758 1-11

Setiawati, J.E.Tarsim. Adiputra,Y.TdanHudaidah,S.(2013).Pengaruh Penambahan Probiotik pada Pakan dengan Dosis Berbeda terhadap Pertumbuhan, Kelulushidupan, Efisiensi Pakan dan Retensi Protein Ikan Patin (Pangasius hypophthalmus). e-Jurnal Rekayasa dan Teknologi Budidaya Perairan, I (2) 150-162

Sukardi, P. Soedibya, P.H.T. dan Pramono,TB. (2018). Produksi Budidaya Ikan Nila (Oreochromis niloticus) Sistem Bioflok dengan Sumber Karbohidrat Berbeda. AJIE - Asian Journal of Innovation and Entrepreneurship, 03 (02) 198-203.

Suminto dan Chilmawati, D. (2015). Pengaruh Probiotik Komersial pada Pakan Buatan terhadap Pertumbuhan dan Kelulushidupan Benih Ikan Gurami. Jurnal Saintek Perikanan; 11 (1) 11-16.

Suryaningrum. F.M (2014). Aplikasi Teknologi Bioflok pada Pemeliharaan Benih Ikan Nila (Oreochromis niloticus). Jurnal Manajemen Perikanan dan Kelautan,1 (1). 9 hal

Tahapari, E., dan Suhenda, N. (2009). Penentuan Frekuensi Pemberian Pakan Untuk Mendukung Pertumbuhan Benih Ikan Patin Pasupati. Berita Biologi, 9(6) 693-698.

Yanti ,Z. Muchlisin, Z.A dan Sugito. (2013). Pertumbuhan dan Kelangsungan Hidup Benih Ikan Nila(Oreochromis niloticus) pada Beberapa Konsentrasi Tepung Daun Jaloh (Salix trasperma) dalam Pakan. Depik, 2 (1) 16-19.

Umasugi, A. Tumbol, R.A. Kreckhoff,R.L. Manoppo,H. Pangemanan, N.P.L dan Ginting, E.L. (2018). Penggunaan Bakteri Probiotik untuk Pencegahan Infeksi Bakteri Streptococcus agalactiae pada Ikan Nila, Oreochromis niloticus. Budidaya Perairan, 6 (2) 39 - 44.

Wijayanti, M . Khotimah,H. Sasanti, A.D. Dwinanti, S.H dan Rarassari, M.A. (2019). Pemeliharaan Ikan Nila (Oreochromis niloticus) dengan Sistem Akuaponik Di Desa Karang Endah, Kecamatan Gelumbang, Kabupaten Muara Enim Sumatra Selatan. Journal of Aquaculture and Fish Health, 8(3) 138-148.

Zulkhasyni. Adriyeni dan Utami, R (2017). Pengaruh Dosis Pakan Pelet yang Berbeda terhadap Pertumbuhan Ikan Nila Merah (Oreochromis sp). Jurnal Agroqua, 15 (2) 35-42. 